\title{
Gametophytes of Botrychium multifidum as Grown in Axenic Culture
}

\author{
ERNEST M. GIFFORD, JR. and DOROTHY D. BRANDON*
}

Mature gametophytes of Botrychium from nature have been described for several species, including B. dissectum (Bierhorst, 1958), B. japonicum (Nozu, 1954; Nishida, 1955), B. lunaria (Bruchmann, 1906), B. obliquum (Campbell, 1921), B. simplex (Campbell, 1922), and B. virginianum (Jeffrey, 1898; Bierhorst, 1958). The gametophytes are subterranean and are tuberous or somewhat elongate to button-shaped. They vary from 1-3 mm to 5-6 mm long, and even reach $1.5-2 \mathrm{~cm}$ in some species. The possession of a "dorsal ridge" in which antheridia are embedded is a typical feature of all the known species. The gametophytes have an associated endophytic fungus, the presence of which presumably is essential for continued growth under natural conditions.

Botrychium spores appear to have a dormancy that is not easily overcome. To date, only the spores of B. virginianum (Campbell, 1895), B. ternatum (du Buysson, 1889), and more recently of $B$. dissectum (Whittier, 1972, 1973a) have been germinated, the last species in axenic culture.

The morphology of the $B$. dissectum gametophytes cultured by Whittier (1972) fits the description for $B$. dissectum from nature, except for the presence of the endophytic fungus. Sucrose and other additives in the medium presumably replaced the contribution of the fungus under natural conditions. The gametophytes, when sexually mature, were only a few millimeters long.

Whittier (1973a) has shown that light inhibits spore germination in B. dissectum. He found that a minimum of 3-4 weeks in darkness is necessary for germination to occur after eight weeks in culture. Increasing the length of the dark period increased the percentage of germination. It is interesting to note that Whittier (1973b) showed that six months of darkness were required for the germination of Psilotum spores.

In this paper we will describe the morphology of Botrychium multifidum (Gmel.) Rupr. gametophytes as grown on a defined medium in axenic culture. The gametophytes of $B$. multifidum have never been observed carefully in nature.

\section{MATERIALS AND METHODS}

Spores for the present study were obtained from a plant in a greenhouse at the Department of Botany, University of California, Davis. The specimen from which the spores were taken has been growing in the greenhouse for several years. It was identified originally as B. multifidum subsp. californicum. However, the results of a recent survey (Stevenson, 1975) have shown that leaves which fit the descriptions of two or more of the presently accepted subspecies of $B$. multifidum can occur in nature on one large, copiously branched plant (which may be more than $100 \mathrm{yr}$. old). Stevenson believes that the recognition of several subspecies of $B$. multifidum is unnecessary, and so we refer the material to $B$. multifidum.

\footnotetext{
*Department of Botany, University of California, Davis, CA 95616.
} 
Spores were surface sterilized in $10 \%$ commercial sodium hypochlorite, washed in distilled water, and sown on a medium recommended by Whittier (1972), which is essentially that of Knudson, except that only $0.2 \%$ sucrose was added to the $0.6 \%$ agar. The $\mathrm{pH}$ was adjusted to 6.3 . The culture tubes were plugged with
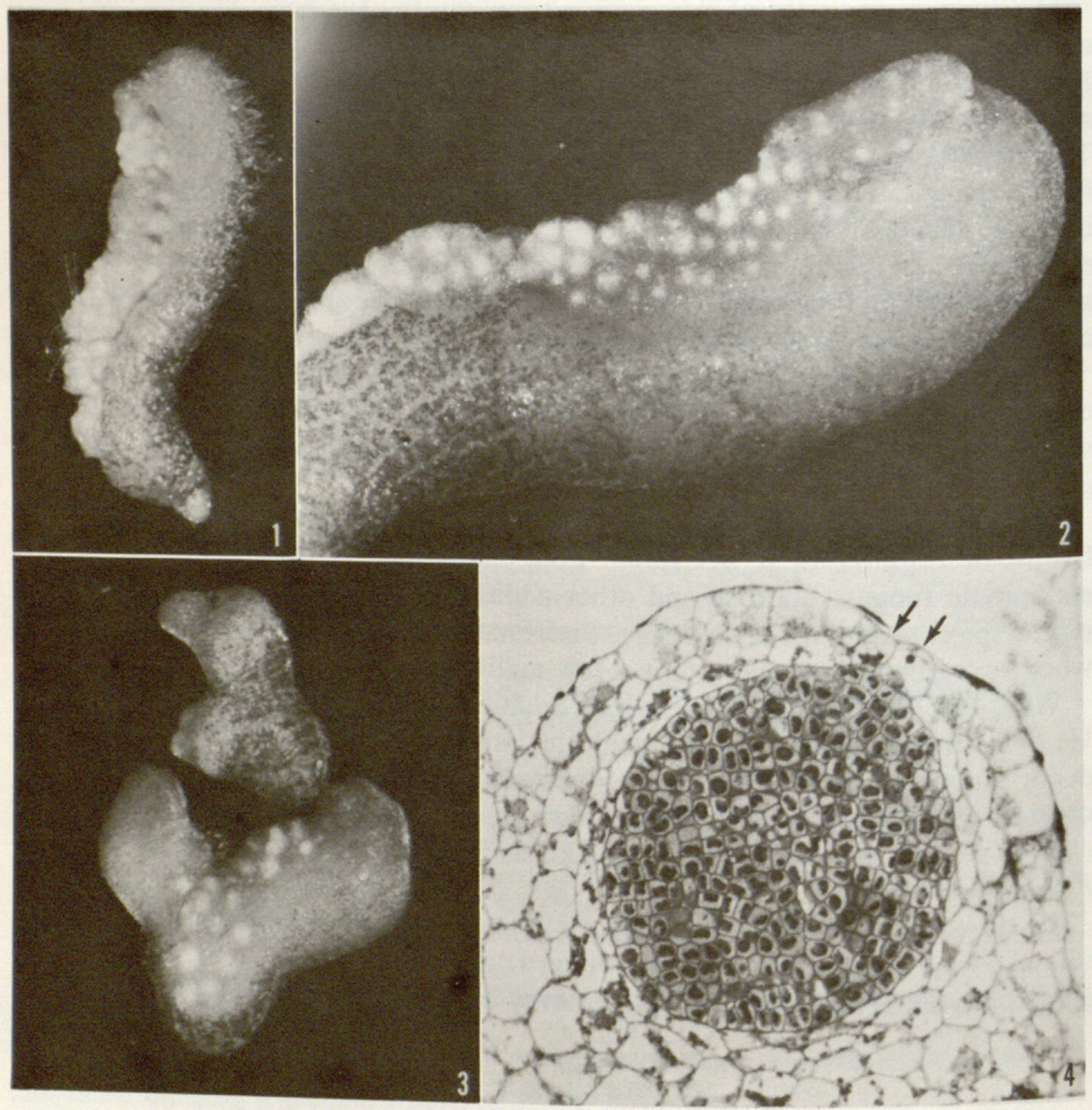

FIGS. 1-3. Various forms of Botrychium multifidum gametophytes grown from spores in darkness for nine months. FIGS. 1 and $3, \times 15$. FIG. 2, $\times 20$. FIG. 4. Transection of antheridium from dark-grown gametophyte of $B$. multifidum; the jacket is 2 or 3 cells thick, and arrows mark two visible opercular cells, $\times 233$.

cotton and capped with polethylene. Knowing that a minimum period of darkness was necessary for spore germination, the innoculated tubes were placed in a dark chamber. Due to an extended leave of absence of the first author, the tubes were not removed from darkness for nine months. No light-grown controls were attempted because it was known from previous experiments that the spores did not germinate in the light. 


\section{RESULTS}

Numerous spores germinated during the nine months in darkness. The resulting gametophytes ranged in size from $0.25 \mathrm{~mm}$ to $2-3 \mathrm{~mm}$; in a few cases they were 0.5 $\mathrm{cm}$ long. The gametophytes were generally obovoid to club-shaped, but in some instances they were irregularly branched (Figs. 1-3). Rhizoids developed on the lower surface or, in some instances, only rhizoid primordia were formed. Except for the smallest gametophytes, a dorsal ridge was present upon which antheridia were embedded (Figs. 1 and 2). The presence of a dorsal ridge is apparently one of the universal features of all Botrychium species thus far investigated. Antheridia were present on the ridge, often in groups (Fig. 1), which may be the result of periodic activity of the apical meristem located at the anterior end, toward the dorsal side (Bierhorst, 1958). No archegonia have been observed, either by inspection of the surface of the gametophytes or in sectioned material. In two instances, we observed reduced, leaf-like structures (not illustrated) which may represent sporophytes, possibly of apogamous origin. In both instances, the leaves consisted of delicate petioles $1-2 \mathrm{~cm}$ long with reduced or abortive laminae. These were produced during the nine months that the cultures were in darkness. The leaves were dead when removed from the culture tubes. The gametophytes to which they were attached were friable, and very little information could be obtained as to the relationship or attachment of the structures. Comparable isolated, apogamously formed leaves have been found in B. dissectum (Whittier, 1976).

Some intact gametophytes that were transferred to fresh medium produced secondary outgrowths (Fig. 5). These newly formed branches developed chlorophyll and became yellowish-green. Branching was limited and the presence of chlorophyll was ephemeral, perhaps as a result of too high a light intensity.

Gametophytes transferred to fresh medium and placed in darkness underwent an extensive proliferation of new apices from the surface of the original gametophytes (Fig. 6). There was no definite pattern of branching, although in some instances the branching appeared to be dichotomous. The new outgrowths were somewhat friable and became dissociated rather easily. Antheridia developed on the dorsal side of some of the new branches.

\section{DISCUSSION}

There are no descriptions of gametophytes of $B$. multifidum from nature. Milde (1858) depicited a young sporophyte with a bulbous base; the latter structure was interpreted as a gametophyte by Clausen (1938), although Milde did not describe it as such. Stevenson (1975) searched without success for gametophytes of $B$. multifidum in several populations in the Sierra Nevada of California. In the absence of gametophytes from nature, it is difficult to know what morphological expression is representative of the species. However, the gametophytes of species already described to date share many similarities: tuberous to somewhat elongate shape, with a dorsal ridge, but varying from $1-3 \mathrm{~mm}$ to $0.5 \mathrm{~cm}$ or more long. For B. multifidum, perhaps the initial form of the gametophyte in culture (club-shaped with a dorsal ridge) is representative of the gametophyte in nature. Whether the 
cultured gametophytes average larger or smaller than those growing under natural conditions is impossible to resolve at present.
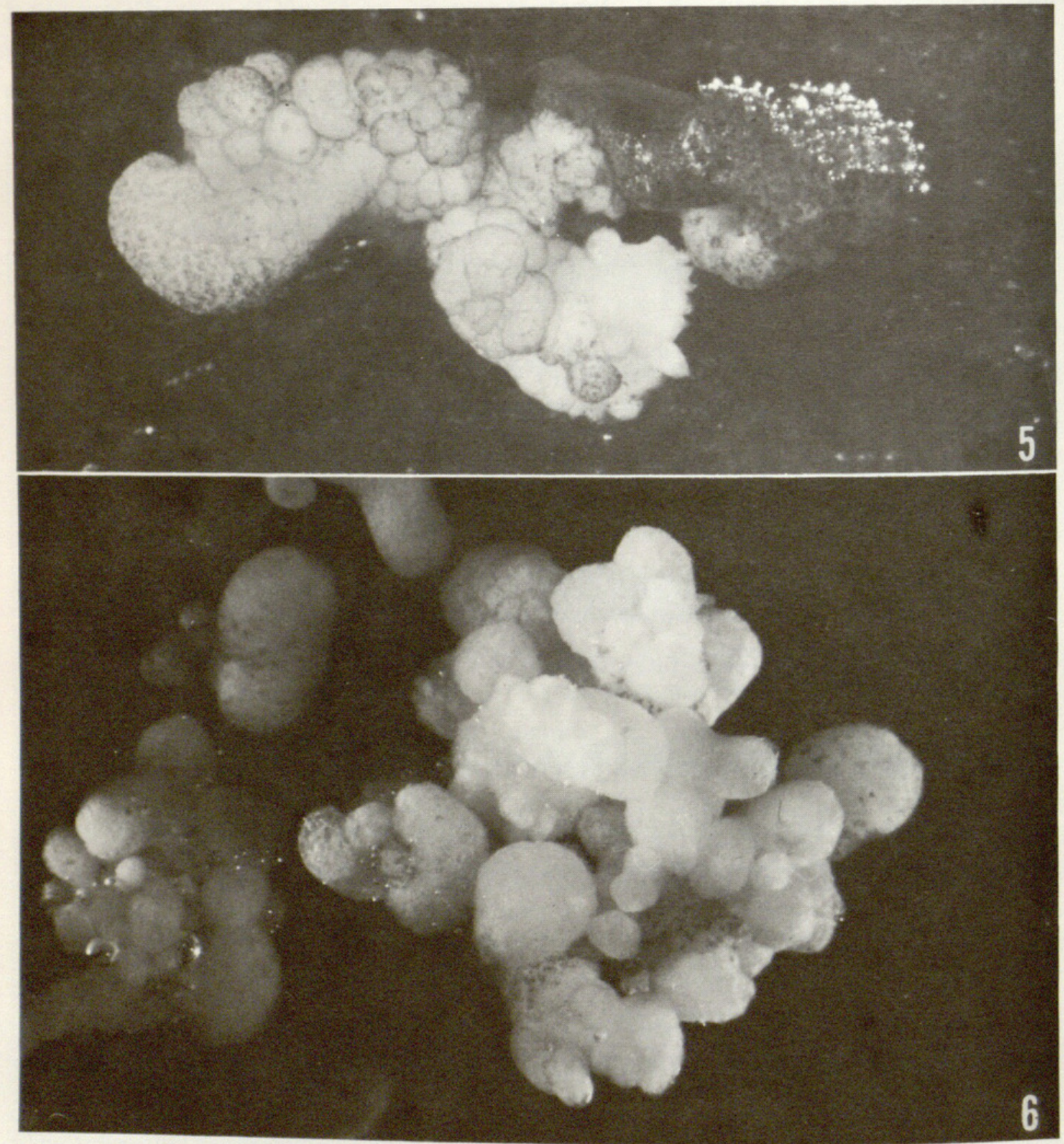

FIG. 5. Botrychium multifidum gametophyte initially grown in the dark, then transferred to light; yellowish-green growth produced in light appears whitish, $\times 12$. FIG. 6. Growth produced from dark-grown B. multifidum gametophytes transferred to fresh medium and maintained in the dark, $\times 15$.

It is quite possible that, in the absence of fertilization and/or apogamous development of sporophytes, the subterranean gametophytes proliferate profusely, as observed in the present study when they are grown in darkness. The clumps could be broken up through action of soil insects, worms, or even larger animals, thereby increasing the dispersal of the gametophytes. Unfortunately, such observations have not been made in nature. 
In the absence of archegonia on cultured gametophytes of $B$. multifidum, one may assume that the two clusters of sporophyte-like structures were of apogamous origin.

\section{LITERATURE CITED}

BIERHORST, D. W. 1958. Observations on the gametophytes of Botrychium virginianum and B. dissectum. Amer. J. Bot. 45: 1-9.

BRUCHMANN, H. 1906. Über das Prothallium und die Sporenpflanze von Botrychium lunaria Sw. Flora 96: 203-230.

BUYSSON, R. du 1889. Monographie des cryptogames vasculaires d'Europe. II. Filicinées. Rev. Sci. Bourbonnais Cent. France 2: 153-164.

CAMPBELL, D. H. 1895. The Structure and Development of Mosses and Ferns, 1st ed. Macmillan, New York.

1921. The gametophyte and embryo of Botrychium obliquum Mühl. Ann. Bot. 35: 141-158.

1922. The gametophyte and embryo of Botrychium simplex Hitch. Ann. Bot. 36: 441-455.

CLAUSEN, R. T. 1938. A monograph of the Ophioglossaceae. Mem. Torrey Bot. Club 19: 1-171.

JEFFREY, E. C. 1898. The gametophyte of Botrychium virginianum. Trans. Roy. Canadian Inst. 5: 265-294.

MILDE, J. 1858. Die Gefässkryptogamen in Schlesien; und ueber Botrychium crassinervium Rupr. und seine Verwandten. Nova Act. Acad. Caes. Leop.-Carol. Nat. Cur. 26: 371-753, 757-767.

NISHIDA, M. 1955. The morphology, gametophyte, young sporophyte and systematic position of botrychium japonicum Und. Phytomorphology 5: 449-456.

NOZU, Y. 1954. The gametophyte and young sporophyte of Botrychium japonicum Und. Phytomorphology 4: 430-434.

STEVENSON, D. W. 1975. Taxonomic and morphological observations on Botrychium multifidum (Ophioglossaceae). Madroño 23: 198-204.

WHITTIER, D. P. 1972. Gametophytes of Botrychium dissectum as grown in sterile culture. Bot. Gaz. 133: 336-339.

1973a. The effect of light and other factors on spore germination in Botrychium dissectum. Canadian J. Bot. 51: 1791-1794.

1973b. Germination of Psilotum spores in axenic culture. Canadian J. Bot. 51: 2000-2001. 1976. Tracheids, apogamous leaves, and sporophytes in gametophytes of Botrychium dissectum. Bot. Gaz. 137: 237-241.

LUST NO MORE!!! after rare ferns, old-world epiphytes, all $18 \mathrm{sp.}$ platyceriums \& many cv's, ferns of Malaysia, Thailand, Phillippines, W. Indies, China. Many unnamed sp. unknown to cultivation, and available here only at The ENDANGERED SPECIES, 842 Walnut Ave., Carpenteria, CA 93013. \$1.00/catalog. 


\section{$2 \mathrm{BHL}$ Biodiversity Heritage Library}

Gifford, Ernest M and Brandon, Dorothy D . 1978. "Gametophytes of Botrychium multifidum as Grown in Axenic Culture." American fern journal 68, 71-75. https://doi.org/10.2307/1546452.

View This Item Online: https://www.biodiversitylibrary.org/item/99454

DOI: https://doi.org/10.2307/1546452

Permalink: https://www.biodiversitylibrary.org/partpdf/230417

\section{Holding Institution}

Missouri Botanical Garden, Peter H. Raven Library

\section{Sponsored by}

Missouri Botanical Garden

\section{Copyright \& Reuse}

Copyright Status: In copyright. Digitized with the permission of the rights holder.

License: http://creativecommons.org/licenses/by-nc-sa/3.0/

Rights: https://biodiversitylibrary.org/permissions

This document was created from content at the Biodiversity Heritage Library, the world's largest open access digital library for biodiversity literature and archives. Visit BHL at https://www.biodiversitylibrary.org. 